Małgorzata Michalewska-Pawlak, Monika Klimowicz, Aldona Wiktorska-Święcka

University of Wrocław

\title{
Understanding the concepts of innovation in regional governance*
}

DOI: $10.19195 / 1643-0328.20 .1$

Keywords: innovation, public management, region, regional governance, civil society

\section{Introduction}

Today, Europe faces socio-economic realities and developmental challenges that drive the need to introduce new solutions which could increase the efficiency of regional development policy. In Europe innovation is being perceived as one of the key means to improve economic competitiveness of various territorial units, including regions. While traditionally the concept of innovation was used mostly with regard to institutions and processes occurring in free market economy, these days it is increasingly applied to the public sector as well. The major incentive for implementing innovative solutions in public governance is their potential contribution to efficient pursuit of society's common interests, which can be generally described as a long-term sustainable development.

Innovation, previously associated mostly with the private sector, is currently present in nearly all areas of the public sphere. However, research on innovation in governance, including regional development, has a much shorter history than that on introducing innovation in the economic sector. Essentially, innovative processes that can be observed in public administration are driven by a logic similar (albeit in some ways unique) to that behind innovation in the free market ${ }^{1}$.

* This publication is a part of research conducted within a project funded by the National Science Centre (Polish: Narodowe Centrum Nauki, NCN), based on the NCN decision no. UMO-2013/09/B/HS5/04522.

${ }^{1}$ R. Rothwell, 'Developments towards the Fifth Generation Model of Innovation', Technology Analysis and Strategic Management, 4/1 (1992), pp. 73-75. 
The purpose of this article is to present the way of understanding innovation in regional development governance, and to emphasise its utility for empirical research on governance implemented in particular regions. The paper focuses on the following issues:

- research conducted to date on innovation in governance and challenges in this area;

- defining public governance as a specific type of governance which, due to its characteristics, should be conducive to implementing innovative approaches;

- regional development governance as a territorially determined form of decision-making, developed within the framework of the multi-level governance concept.

The main part of the article is focused on innovation in public governance and the possibility of utilising the concept proposed here in empirical research on particular regions.

The methodology for analysing innovation in regional governance proposed in this paper should contribute to the discourse on principles and directions of intra-regional policy, activity, creativity and effects of work conducted by regional authorities and civil society in the process of governing their territories.

\section{Current state of research on innovation in governance and challenges in this area}

Research conducted in Europe on innovation in regional development governance refers largely to organisational innovation in the public sector. It results from applying methodology used in the studies of management to the problem of innovativeness of the public sphere ${ }^{2}$.

Innovation in the public sector encompasses most of all the introduction of new public services, policies and programmes, as well as the development of new approaches and processes in providing public services. Many years of research and experience gathered by practitioners has allowed scholars to create a fairly broad definition of innovation in public administration governance ${ }^{3}$. As this subject receives a lot of attention, both in the public debate and in strategic activities undertaken by authorities at various levels (including the supra-national level), recent years have witnessed an increasing num-

2 See: C. Bason, Leading Public Sector Innovation: Co-Creating for a Better Society, Bristol 2010; W.D. Eggers, S.K. Singh, The Public Innovation's Playbook: Nurturing Bold Ideas in Government, Ash Institute for Democratic Governance and Innovation, John F. Kennedy School of Government, Harvard University 2009, http://www.innovations.harvard.edu/public-innovators-playbook-nurturing-bold-ideas-government, (retrieved: 4.10.2015); M.H. Moore, J. Hartley, 'Innovations in Governance', [in:] The New Public Governance? Emerging Perspectives on the Theory and Practice of Public Governance, ed. S.P. Osborne, London 2010; R. Hambleton, J. Howard, 'Place-Based Leadership and Public Service Innovation', Local Government Studies 39/1 (2013).

3 A. Alberti, G. Bertucci, 'Replicating Innovations in Governance: An Overview', [in:] Innovations in Governance and Public Administration. Replicating What Works, ed. A. Alberti, C. Bertucci, Department of Economic and Social Affairs United Nations New York 2006, http://unpan1.un.org/intradoc/groups/public/ documents/un/unpan021963.pdf, pp. 3-6 (4.10.2015). 
ber of publications on innovative methods and instruments in public administration governance ${ }^{4}$. European Union (EU) member states are more willing to enhance their institutional systems by introducing innovative ideas into the practice of governance (for example, the German governmental programme entitled Zukunftsorientierte Verwaltung durch Innovationen. Regierungsprogramm, BMI 2006). Public administration governance is increasingly subjected to interdisciplinary research incorporating elements of political sciences, management, economy, administration and law ${ }^{5}$. Innovation in this area is associated with changes within the administration (from bureaucratisation to new public management) or placed in the context of the evolving socio-political and economic situation - for instance, the emergence of new technologies 6 .

Research conducted to date on innovation in Polish regions has been focused on pro-innovation policies introduced by regional authorities, the functioning of regional innovation systems, the utilisation of regions' innovative potential, as well as the innovativeness of entities and companies located in a given territorial unit ${ }^{7}$. Several of the recently published materials touch upon the concepts of implementing smart specialisations in regional development ${ }^{8}$. Such ideas stem directly from the provisions of the EU 2014-2020 regional policy, according to which regions are obliged to prepare development strategies based on their endogenous potential. Such strategies should include innovative initiatives aimed at contributing to smart growth ${ }^{9}$. Apart from the regional aspect, there is abundant literature devoted to innovation in managing various types of organisations, particularly businesses ${ }^{10}$.

${ }^{4}$ See: S.P. Osborne, L. Brown, 'Innovation, Public Policy and Public Services Delivery in the UK. The Word That Would Be King?', Public Administration 84/4 (2001), pp. 1335-1350; C. Pollitt, 'Innovation in the Public Sector: An Introductory Overview', [in:] Innovation in the Public Sector - Linking Capacity and Leadership, ed. V. Bekkers, J. Edelenbos, B. Steijn, New York 2011, pp. 35-43; C. Bason, op. cit.

${ }^{5} \mathrm{~J}$. Bott, Die Wirkung von Macht auf Innovationen innerhalb einer öffentlichen Verwaltung, Kassel 2013.

6 D. Grunow, Innovationen in der öffentlichen Verwaltung, Handbuch Innovationen. Interdisziplinäre Grundlagen und Anwendungsfelder, Wiesbaden 2014.

7 See: A. Pawlik, Potencjał innowacyjny w rozwoju regionalnym, Kielce 2012; Z. Makieła, Przedsiębiorczość i innowacyjność terytorialna. Region w warunkach konkurencji, Warszawa 2013; T. Geodecki, Ł. Mamica, Polityka innowacyjna, Warszawa 2014.

8 D. Miłek, 'Specjalizacje regionalne a Strategia Europa 2020', Journal of Management and Finance 11/1 (2013), part 2, Sopot 2013, pp. 189-199; K. Pytlak et al., Procesy innowacyjne a rozwój regionu, Lublin 2014, pp. 11-27.

${ }^{9}$ Smart growth, as defined in the Europe 2020 strategy, provides for improving the level and quality of education (with the purpose of increasing vocational qualifications and competence of the human capital), using academic research as a source of innovation for economic growth, increasing the employment rate, resolving social issues and building a digital society able to utilise IT and communication technologies (European Commission, Europe 2020. A European Strategy for Smart, Sustainable, and Inclusive Growth, Brussels 2014, http://ec.europa.eu/europe2020/europe-2020-in-a-nutshell/priorities/smart-growth/index_en.htm (retrieved: 4.10.2015)).

10 See: M. Brzeziński, Zarządzanie innowacjami technicznymi i organizacyjnymi, Warszawa 2001; K. Kozioł-Nadolna, W. Janosz, Innowacje w organizacji, Warszawa 2011; J. Penc, Innowacje i zmiany w firmie, Warszawa 2011. 
There is, however, a clear deficit of research (both theoretical and empirical) on innovativeness in public governance. Polish literature published so far is focused mainly on analysing models of public governance in the context of Polish social, political and economic realities ${ }^{11}$. Some research has also been conducted on the level of innovativeness observed in regional and local administration ${ }^{12}$. Innovation in public governance has been only marginally touched upon, for example in the primarily theoretical works by Barbara Kożuch ${ }^{13}$.

Researchers examining innovation in regional development governance face two major challenges. The first one can be encapsulated in the following question: Which governance solutions are innovative? In other words - what criteria should be used to determine whether a given regulation, instrument or procedure employed by public authorities in the process of governance can be deemed innovative? The questionable nature of such criteria is only deepened by the fact that European countries vary substantially in their administrative cultures and models of public governance introduced at particular levels of territorial administration. As conditions in which governance solutions are implemented also vary (with respect to partnerships or the involvement of civil society), any analysis of innovative solutions has to account for territorial, historical and cultural context. For instance, one can easily predict that innovations in regional development implemented in Central and Eastern Europe will differ in character from those introduced in the West of the continent. If for no other reason, this will be true due to differences in the extent to which cooperation between the authorities and society is institutionalised, or to differing political cultures among European nations (as expressed in societies' readiness to participate in governance processes). Democratic governance has a much longer tradition in Western Europe than in the former Soviet bloc countries. Therefore, one can expect that innovations introduced by the latter will be more imitative than genuinely pioneering, although this hypothesis needs to be verified through empirical research ${ }^{14}$.

As Udo Diedrichs noted: "it is not easy to find an example of decision-making mechanisms that had previously not been used" ${ }^{\prime 2}$. This is why it is worth examining all inventive solutions introduced to public governance, even if one cannot judge to what extent

11 J. Hausner, Zarządzanie publiczne, Warszawa 2008; F. Kuźnik, 'Stare i nowe koncepcje zarządzania publicznego w strukturach samorządu terytorialnego, [in:] Z teorii i praktyki zarządzania publicznego, ed. B. Kożuch, T. Markowski, Białystok 2005, pp. 68-79.

12 See: A. Tuziak et al., Innowacyjność i rozwój, Rzeszów 2006; T. Markowski, B. Banachowicz, 'Innowacyjność w samorządzie terytorialnym, [in:] Z teorii i praktyki..., pp. 90-102.

13 See: B. Kożuch, 'Innowacyjność w zarządzaniu publicznym', [in:] Nowe zarządzanie publiczne i public governance $w$ Polsce $i w$ Europie, ed. A. Bosiacki et al. Warszawa 2010, pp. 31-46; B. Kożuch, A. Kożuch, 'Innowacyjność w zarządzaniu rozwojem lokalnym', Journal of Agrobusiness and Rural Development 3/25 (2012).

14 Since 2014, the authors of this paper have been conducting research aimed at verifying the above-mentioned hypothesis. The research is enabled by an $\mathrm{NCN}$-funded project entitled 'Innovation in regional development governance in Poland' (NCN decision no. UMO-2013/09/B/HS5/04522).

15 U. Diedrichs, Metody zarządzania w Unii Europejskiej, [in:] Nowe metody zarządzania w państwach Unii Europejskiej, ed. L. Kolarska- Bobińska, Warszawa 2009, p. 24. 
they are truly innovative. Instead, one may focus on important changes they introduce into the process of shaping/implementing public policies and achieving development goals. One unquestionable criterion they should meet is falling within the category of good governance, with its inherent responsibility for growth (in all its different contexts) and inclusion of communities affected by the process ${ }^{16}$.

The second challenge to be faced by researchers in this field is related to determining the correlation between innovation in regional governance and the dynamics of GDP growth. It is practically impossible to establish a direct link between these two phenomena, since both the level of economic development and the rate at which it progresses in a given region are driven by a cumulative impact of numerous direct and indirect factors. However, by conducting comparative research and analysing case studies, one can discover whether or not a dynamic growth of regional GDP is accompanied by innovations in developmental governance.

\section{Public governance as a category of management}

In modern administration, the public governance model emerged as a reaction to passivity and low efficiency of bureaucratic structures in processing public matters. It is also a constructive response to weaknesses of New Public Management model, which has been evaluated as inadequate to the specificity of the public sector ${ }^{17}$. This model contrary to the public governance model - has been described in the current Polish theoretical literature ${ }^{18}$. That is why it seems worth concentrating on the presentation of assumptions of public governance, which implies that public institutions should seek efficiency and maximise society's benefits from the way they exercise their authority. It also provides for more partnership-like relations between these institutions and the public $^{19}$. Hence, the impact of governance stretches beyond mere public sector ${ }^{20}$, as the model involves social and private entities, as well as civil society at large, in the process of shaping public policies. According to Diedrichs, governance as a model is innovative in itself, since its approach to the communal decision-making process differs from that in the traditional governing. While the latter is based on hierarchy and domination of authorities, the former stems from interactions and cooperation between public and private actors of various levels ${ }^{21}$.

16 T. Borys, „Koncepcja dobrego rządzenia - istota, cechy swoiste, pomiar”, [in:] Dobre rządzenie w gminach matych. Empiryczny wymiar nowego paradygmatu rozwoju vol. 1., ed. K. Kobielska, A. Lisowska, Bydgoszcz 2014, p. 57.

17 Narastające dysfunkcje, zasadnicze dylematy, konieczne działania. Raport o stanie samorzadności terytorialnej w Polsce, ed. J. Hausner, Kraków 2013, p. 78.

18 A. Podgórniak-Krzykacz, 'Rozwój lokalny a dobre rządzenie - przegląd wybranych założeń wybranych strategii rozwoju lokalnego', Zeszyty Naukowe Wyższej Szkoły Zarządzania i Finansów, 27 (2009).

${ }_{19}$ K. Lisiecka, T. Papaj, E. Czyż-Gwiazda, Public governance koncepcją zarządzania w administracji publicznej, Katowice 2011, p. 38.

20 F. Kuźnik, op. cit., p. 70.

${ }^{21}$ U. Diedrichs, op. cit., pp. 14, 17. 
The first concepts of public governance emerged toward the end of the 1980s. Their proponents explained that the mechanism at work in the private sector was simple: managers gathered capital thanks to the choices made autonomously by clients or from investors who were hoping to find new consumers; in any case, customer satisfaction was the utmost goal. They also argued that it was advisable to transfer this mechanism to the public sector as a remedy to weaknesses and inefficiency exhibited by the bureaucracy in public administration.

In public governance, the key criteria are:

- efficiency - the goal here is to maintain or broaden the scope of public services while decreasing the cost of resources needed by the system;

- market-like operation - public administration uses free market mechanisms to minimise weaknesses of traditional bureaucracy;

- being service-oriented - strengthening the links between the government and citizens and focusing on customers' (citizens') satisfaction with the quality of public services;

- decentralisation - an effort to position decision-making entities as close as possible to the communities affected by their decisions;

- accountability - the attitude whereby public institutions are obliged to keep promises they make and meet obligations they undertake ${ }^{22}$.

Such a vision of public governance, with its references to the market principles of competition, autonomy and deregulation, found approval of the largest international organisations (including the United Nations) and began to be promoted and recommended as an emerging standard in public administration ${ }^{23}$.

Today, public governance constitutes a combination of two orientations in the management of public matters: a normative one - characteristic of traditional public administration, and an instrumental one - used generally in management, with the latter being applied mostly to analysing decision-making processes and managerial activities with regard to selecting appropriate instruments and achieving goals.

\section{Steering vs. managing vs. governing}

The last two decades have seen a shift in thinking about the public sector, also with regard to the question of the role of administration in managing public matters. This change resulted from the satiety with the efficiency-oriented concept of public management on the one hand, and vocal criticism of its shortcomings (including the claim that is was based on an excessively narrow set of principles focused around market-like operation and maximisation of benefits) on the other. What emerged from the shift was the idea of governance - a construct that envisioned building public value as a key func-

22 D.F. Kettl, The Global Public Management Revolution. A Report on Transformation of Governance. The Brookings Institution, Washington 2001, as quoted in: J. Supernat, 'Administracja publiczna, governance i nowe publiczne zarządzanie,, [in:] Prawna działalność instytucji społeczeństwa obywatelskiego, ed. J. Blicharz, J. Boć, Wrocław 2009, pp. 139-146.

23 See: United Nations, Resolution adopted by the General Assembly: Promoting and consolidating democracy, A/RES/55/96, New York 2000. 
tion of the public sector. One implication of this new idea was that public management required not only an efficient administration, but also a well-organised, educated and responsible civil society - that is, individuals and groups that pursued common public interests, also outside the public sector ${ }^{24}$. Such a model implies that public management is a process based on non-hierarchical relations between smoothly operating authorities and civic entities engaged in the implementation of public tasks. If the model is to be successfully applied in practice, both parties have to build a sufficient potential. As indicated by Tanja Börzel, authorities are more willing to cooperate with non-public bodies if they possess certain resources: information, knowledge and human capital. Such non-hierarchical coordination fails when public institutions are weak and fear losing their autonomy to the private sector ${ }^{25}$.

Governance signifies order, foundation, basis, a set of values upon which companies, public and private institutions have been building their identity since the mid-1990s. The term was translated into Polish in several different forms, such as zarzadzanie wielopoziomowe (the most literal English translation would be 'multi-level governance'), ład korporacyjny ('corporate governance'), but also dobre rzadzenie ('good governance' $)^{26}$. It describes principles which govern the way of regulating various issues and complex processes involving different private, public, non-governmental, formal and informal entities. Since these entities are numerous and vary greatly in structure, competence profile and scope of activities (hence, responsibility), one may feel compelled to reconsider whether the term "management" is adequate to this phenomenon and reflects its conceptual breadth.

So far, Polish literature on the subject has not employed the internationally used term "steering" 27 . Proponents of the new approach argue that in today's dynamically changing realities, management, with its traditional functions of planning, organising, motivating, implementing and supervising, is no longer possible. The concept of governance - understood as a process of coordinating (or steering) a complex society by involving entities from both public and private sectors - is better suited to reflect the nature of what actually occurs. In governance, the actors involved often operate in a networked structure, where the central point is no longer reserved exclusively for public administration $^{28}$. The model proposes new types of interactions between the state and society, and recommends multi-dimensional forms of cooperation. Such a pattern of regulating the issues of common interest provides for the involvement of citizens in the process of building public goods and delivering services. This way, it creates a framework within

${ }^{24}$ A. Wiktorska-Święcka, 'Governance jako nowy paradygmat sterowania rozwojem w procesach integracji europejskiej’, [in:] Procesy integracyjne i dezintegracyjne w Europie. Podręcznik akademicki, ed. M. Klimowicz, A. Pacześniak, Wrocław 2014, pp. 147-178.

25 T.A. Börzel, 'Nowe metody zarządzania a rozszerzenie Unii Europejskiej - paradoks podwójnej słabości', [in:] Nowe metody zarządzania w państwach Unii Europejskiej, ed. L. Kolarska-Bobińska Warszawa 2009, p. 83.

${ }^{26}$ J. Hausner, Zarządzanie..., op. cit., p. 8.

27 M. Haus, 'Governance, Meta-Governance und die Transformationen lokaler Institutionen', [in:] Local Governance - mehr Transparenz und Bürgernähe, ed. L. Schwalb, H. Walk, Wiesbaden 2007, p. 68.

28 R.J. Grote, 'Local Governance und organisierte Zivilgesellschaft', [in:] Local Governance..., pp. 43. 
which individuals can express their needs and problems, while the state or society can respond to and remedy them. It also allows for the creation of various civic self-help mechanisms, some of which may be situated entirely outside the structure of public authorities. Governance promotes comprehensive accountability, with many stakeholders engaged in the process (on the part of both decision-makers and recipients). It refers to cooperation as "partnership" and emphasises it as a key form of involvement. Furthermore, it calls for new ways of cooperating, new competences and leadership that require political independence, awareness, openness and sensibility. Theorists of governance have identified certain elements common to different concepts of this model, which can serve as the foundation for understanding it:

- steering and coordination (or governing) aimed at managing interdependencies between actors;

- institutionalised regulatory systems that guide actors' actions; preferred forms are typically combinations of various systems (market, hierarchy, majority rule, negotiations);

- patterns of interactions and collective actions that stem from the framework imposed by institutions (networks, coalitions, contracts and agreements, competition through cooperation);

- steering and coordination processes, along with patterns of interactions, often exceeding the boundaries of a single organisation - particularly, the state or society ${ }^{29}$.

Governance does not provide for the creation of new structures - instead, it proposes optimising the already existing ones according to current economic, social and institutional conditions. The focal point, therefore, is the function and ability to perform public tasks in the most efficient manner possible, rather than the construction of fresh structures.

The debate over governance is closely linked to the current discussion on regulatory norms and the desirable division of policy-making competence between various levels of authorities. The latter subject originated from EU Cohesion Policy and the discourse on its future. The same discourse also touched upon the issue of the best distribution of competence among EU, national, regional and local-level authorities, as well as roles given to particular actors in the implementation of Cohesion Policy. The whole theoretical debate coincides with a number of initiatives undertaken by EU member states with the goal of modernising the public sector by decentralising authority, providing regional and local self-governments with appropriate rights and competences, and determining the scope of responsibilities to be given to each public administration unit according to the subsidiarity principle ${ }^{30}$. All in all, over the last decade the issues of innovation and regional governance have become increasingly relevant, particularly in light of the ongoing pursuit of competitiveness on the part of many EU regions.

29 Z. Benz, Governance - Regieren in komplexen Regelsystemen: Eine Einführung, Wiesbaden 2004, p. 18.

30 See: M. Michalewska-Pawlak, 'Europeizacja samorządu - wpływ Unii Europejskiej na aktorów lokalnych i regionalnych', [in:] Europeizacja - mechanizmy, wymiary, efekty, ed. A. Pacześniak, R. Riedel, Toruń 2010. 


\section{Steering the process of regional development}

In the concept of governance, regions constitute vital subjects of the developmental policy. Their definition is not limited to structures - they also encompass functional areas (for instance those related to the economy, labour market or culture). The term regional governance signifies forms of regionally determined steering process at the intermediary level, supplemented by the market and the state. Adopting such a definition results in the need to refer to the concept of multi-level governance which envisions actions undertaken by regional actors in the process of negotiations and creating cooperative networks. Apart from the geographical perspective, one feature characteristic of multilevel governance in the regional dimension is its voluntary-based self-controllability. Cooperation between various actors does not always require a formal framework, and it is not limited to traditionally shaped systems (political sphere/administration, economy, society). It occurs whenever solving a given problem calls for sharing resources and undertaking collective efforts. Apart from that, regional governance indicates a process closely connected with local, national and European policy. Just as at the local level, active engagement and mutual trust between the actors guarantee that the cooperative network is maintained and developed. However, in regional governance, unlike in local or national governance, the primary goal is to manage the network of interdependencies and enhance institutional efficiency. Multi-level governance at the national level is focused on the political-institutional dimension, while at the local level it is mainly about cooperation and partner-like, often informal relations that result in the strengthening of social capital. Institutional efficiency is only of secondary importance. Regional multilevel governance is characterised by:

- cooperation between actors who follow different logic;

— crossing traditionally defined fields and sharing competences among different systems;

- self-organised networks of interdependencies;

- horizontal forms of interactions based on argumentation and negotiations, rather than forms of power and constraint;

- self-determined (through negotiations) regulatory systems that ensure formal streamlining of interactions, reduce transaction costs and increase actors' certainty as to whether their expectations will be met;

- extensive pragmatism and rationality of all undertaken actions (with the important role of the learning process) ${ }^{31}$.

The above-mentioned criteria can be supplemented with more detailed characteristics of multi-level governance. First of all, such governance in its regional dimension exists only when a regional steering process has been established as a permanent form of managing development. Secondly, although it may refer to singular activities, it has to ensure cohesion and coordination of all implemented projects. Effective regional governance which takes place within the framework of a multi-level system requires adopting

31 W. Maloney, G. Smith, G. Stoker, 'Social Capital and Urban Governance: Adding a More Contextual “Top-Down” Perspective', Political Studies, 48 (2000). 
a strategic approach to planning and implementing developmental activities. It is particularly so since the conditions in which such activities will be implemented are often determined at levels of authority other than regional (in case of the EU this may also be a supra-national level). By defining strategic developmental goals, stakeholders can minimise conflicts that naturally occur between various groups as a by-product of their involvement in the decision-making process. Long-term strategic planning, based on a diligent analysis of strengths and weaknesses, allows regions to better utilise their endogenous potential and avoid risks associated with personal changes within the authorities responsible for regional development. Strategies frequently span a period longer than a single term of office and oblige any newly elected public officials to consequently pursuit long-term goals.

Experience shows that intensified cooperation contributes to the shaping of social capital as well as strengthens partners' identification with the region ${ }^{32}$. One frequent element of regional governance is project-based work. This can be explained by the fact that overcoming state-centric logic seems possible and desirable in situations when the division of tasks among all interested, competent stakeholders guarantees the possibility of producing comprehensive solutions, often tailored specifically to a given geographical area. Empirical observation leads to distinguishing the two basic types of governance: one referring to a territory, and another to function. Politicians are focused on the territorial dimension, since their thinking is oriented toward units of territorial self-government and their respective competences. Meanwhile, companies act with function in mind: they turn toward entities with which they can establish a beneficial cooperation, regardless of where these entities operate. Still, the spatial aspect is not entirely without relevance, since covering long distances inevitably generates some costs. This is why enterprises work toward creating regional production systems - narrowly specified networks of connections with other companies, research and educational institutions. Regional governance requires a steering process oriented toward an entire region. However, in practice its forms are frequently function-centred - they are based around specific problems and adopted during the implementation of projects designed with a specific purpose in mind. Hence, the way regional governance is implemented may dynamically change: the more able multi-level governance instruments are to solve problems without involving traditional institutions, the more often they will be employed.

Regional governance is one of the key elements of the EU regional policy. Official EU publications describe it as a political system of institutions interconnected at numerous levels, exhibiting unique characteristics of a single policy - multi-level governance ${ }^{33}$. Multi-level governance, in turn, is defined as a flexible distribution of power in such a way that no single institution holds exclusive competence to make final decisions. It signifies multiple combinations of authorities and governments at various levels: from the

32 B. Geißel, 'Zur (Un)Möglichkeit von Local Governance und Zivilgesellschaft. Konzepte und empirische Befund', [in:] Local Governance..., p. 30.

33 D. Bailey, L. De Propris, 'EU Structural Funds, Regional Capabilities and Enlargement: Towards Multi-Level Governance?', Journal of European Integration, 24 (2002), p. 305. 
European level to regional cooperation networks. Relations between these actors are based on sharing resources rather than competing for them ${ }^{34}$. Decisions made locally are functionally interrelated based on connections between national policies of $\mathrm{EU}$ member states and policies implemented at the European level. Therefore, modern regional governance becomes a conglomerate of traditional forms of administrative management and networked cooperation involving a wide range of local organisations, entrepreneurs, academic centres and other actors of the public sphere. Meeting regional developmental goals (such as supporting entrepreneurship, supplying local demand for the human capital, cluster growth or increasing innovativeness) often requires a bottom-up process of creating local and regional strategies. Such an approach takes account of the characteristics of a given region and enhances cohesion of all decisions made regionally. It also improves the quality of governing and contributes to the growth of social capital in local communities. Finally, it encourages innovative solutions aimed at developing a given geographical area.

\section{Innovation in regional governance}

The literature on this subject contains several definitions of innovation. However, not all of them are useful for analysing changes and effects of regional governance. The term "innovation" has been given many meanings, as proposed by authors such as Drucker, Schumpeter, Kotler, Romer, Lucas or Silberberg. A glance at academic publications reveals that innovation is a research area encompassing exact and social sciences, as well as humanities. The word itself has its origins in the Latin term innovare, which means 'to restore', 'to refresh' or even 'to create something new'. Consequently, most definitions of innovation emphasise that it is a process of transforming current potential into new ideas that can be applied in practice - if not now, then in the future.

One of the first definitions of innovation, rooted in economics, comes from Joseph Schumpeter ${ }^{35}$. His explanation of the term is fairly narrow, as it is limited to pointing out innovative technical aspects of business operations. It emphasises practical applicability and improved economic performance that should stem from implementing innovation $^{36}$. However, innovativeness (the ability to generate and implement innovation) can refer not only to technical or technological developments, but also to organisational aspects and, within this field, to management. Innovation in management may be perceived as one of the key factors that affect performance and growth of contemporary or-

34 L. Hooghe, G. Marks, Multi-Level Governance and European Integration, Lanham 2001, p. 18.

35 Joseph Schumpeter, who first used the term "innovation" in its modern sense, identified it with releasing new goods, implementing new production methods, creating a new market, gaining access to a new source of raw materials or reorganising a given industry. See: J.A. Schumpeter, Teoria rozwoju gospodarczego, Warszawa 1960, p. 104.

36 P. Niedzielski, K. Rychlik, Innowacje i kreatywność, Szczecin 2006, p. 19. 
ganisation operating in a turbulent environment ${ }^{37}$. Moreover, in highly developed countries management innovation is believed to be one of the major (if not the most crucial one) elements of solutions aimed at counteracting the negative effects of the financial crisis the world has been combating for the past few years.

Determining the appropriate way of defining innovation in management is a good starting point to constructing an analytical model for examining this phenomenon in regional governance. New methods of management signify innovation in comparison to earlier solutions ${ }^{38}$. Still, looking at innovation only through the lens of the temporal continuum seems imprecise and insufficient. Is everything new innovative? It would also be prudent to look for correlation between the "new" and the "beneficial", so that one can establish whether changes dubbed as innovations actually bring positive results.

Adriana Alberti and Guido Bertucci point out significant benefits stemming from implementing innovation in administration and public management. First of all, innovation enables better optimisation of the way we use resources to create common benefits. Secondly, it generally improves the standard of governance, also through enhancing the culture of openness and participation. Furthermore, since it enables better quality of services, it builds citizens' trust in authorities and provides the latter with broader legitimisation. It fosters "the culture of improvement", as it tends to spread from one area to another. The authors stress that typically, innovation comes in the shape of little positive changes, but that the accumulated results of these changes can lead to a substantial transformation in governing a country ${ }^{39}$.

Initiating and implementing innovation in public management is somewhat different than in the private sector, since the former is oriented toward the realisation of public tasks, and at the same time is limited by numerous legal regulations that may hinder innovative ideas or actions. Nonetheless, the growing importance of efficiency in public management has resulted in the need to search for new solutions that would enable the pursuit of public tasks in a manner less bureaucratised and authoritarian than in the administrative model. This is why new concepts evolve from public management toward public governance ${ }^{40}$. In this novel approach, regional governance is characterised by such a pattern of planning, organising and implementing public tasks at the regional level which accounts to the greatest possible extent for genuine involvement of all stakeholders operating in the environment around regional public administration.

One of the contemporary trends, new public management, stresses that if services offered by the public sector are to be delivered more efficiently, the sector itself has to be managed with the use of certain market mechanisms ${ }^{41}$. However, one needs to re-

37 T. Kraśnicka, 'Innowacyjność zarządzania w rozwoju współczesnych organizacji (aspekty teoretyczne)', [in:] Strategie zarządzania organizacjami w społeczeństwie informacyjnym, ed. A. Stabryła, T. Małkus, Kraków 2014, p. 199.

38 U. Diedrichs, op. cit., pp. 14-16.

39 A. Alberti, G. Bertucci, op. cit., p. 2.

40 A.V. Anttiroiko, S.J. Bailey, P. Valkama, 'Innovations in Public Governance in the Western World', [in:] Innovations in Public Governance, ed. A.V. Anttiroiko, S.J. Bailey, P. Valkama, Amsterdam 2011, pp. 1-2.

${ }^{41}$ K. Lisiecka, T. Papaj, E. Czyż-Gwiazda, op. cit., p. 46. 
member that the purpose of public management is to meet the needs of society, some of which cannot be fulfilled by means of a free market economy. Therefore, while market logic can be seen as a way to increase the efficiency of the public sector, it should not be considered as a paradigm for its functioning. This is why not every solution transferred from business to public management can be treated as innovative.

Nonetheless, applying theoretical-methodological approaches used in research on management to innovation in regional governance seems justified. By doing so, one can capture the essence of innovative management in the public sector, which can be described as a novel way of performing public tasks based on new or previously unused knowledge. Literature on economics contains four major perspectives on the subject:

- institutional - where research is focused on the socio-economic environment in which new concepts and practices of management are shaped;

- implementation style - where research revolves around the dynamics of mutual relations between the creators and users of managerial innovation;

- cultural - which focuses on how organisation reacts to newly introduced practices of management;

- rational - which refers to how innovation and managers behind it affect the efficiency of organisations ${ }^{42}$.

Polish scholars have also contributed to research on innovation in regional governance. According to Barbara and Antoni Kożuch, innovation constitutes a source of increased efficiency on the part of self-government administration. It is characterised by:

- substantial radicalism,

- relevance to new theories and concepts,

- sudden change of conditions in which the administration operates,

- technological breakthrough,

- ability to bring results that reflect a possibly redefined mission ${ }^{43}$.

The same authors indicate that innovative management in public administration emerges as a separate model which, although it shares several features with other concepts, such as public governance or new public service, exhibits a number of entirely unique characteristics. Innovative management in public administration is rooted in theories of democracy, civil society, social capital and managing organisational changes. It envisions innovativeness as essential for determining strategic goals, developing partnerships or coordinating public policies, programmes and other undertakings. Moreover, it maintains that innovativeness supports sustainable development model, whereby public interest emerges as an expression of values shared by society, while the way such interest is being pursued results from negotiations between numerous stakeholders ${ }^{44}$.

For analysing innovation in regional governance, one may utilise a three-part analytical model. It consists of three interrelated areas that are vital for verifying the concept.

42 J. Birkinshaw, G. Hamel, M.J. Mol, 'Management Innovation', Academy of Management Review, 33/4 (2008), p. 825.

43 B. Kożuch, A. Kożuch, op. cit., p. 138.

44 Ibidem, p. 139. 
The first of these refers to subjects participating in regional governance. One should remember that in the traditional model of public management authorities, which are not obliged to involve any other subjects in their actions, occupy the central place. Regional governance introduces new solutions which account for the importance and impact of active participation on the part of such entities as social organisations, lobbies, trade unions, associations, employers' organisations, educational and research centres, media, etc. If one understands innovation in regional governance as an introduction of new solutions into the practice of public management, it becomes clear that any research on the matter should include thorough evaluation of quantitative analysis of subjects engaged in regional governance - in other words, one needs to examine changes in the number of entities involved in decision-making and implementation of regional strategies and development instruments. This should lead to establishing what trends occur in this area, as well as what criteria and procedures are used for selecting civil society actors who are encouraged to cooperate with the authorities.

The second dimension in the analysis of innovation in regional governance should focus on the decision-making process. Scholars willing to undertake research on this subject should examine: forms and methods of interactions between different entities participating in decision-making; channels and effects of communication, exchanging information and other resources; forms and scopes of participation on the part of various types of entities. Here, one methodological cornerstone is the systemic and institutional approach. Another important aspect is the analysis of impact that particular actors have on regional governance. Hence, in evaluating innovation in the decision-making process, one has to critically, realistically verify both the influence of all actors and instruments allowing for their participation.

Finally, the third pillar of the analysis requires confronting the concept of innovativeness with the effectiveness of political actions undertaken at the regional level. The political effect (that is, results stemming from actions undertaken by entities involved in regional governance) has to be translated into a measure of efficiency with which regional governance is being implemented. In the analysis of socio-economic development, key indicators of efficient management will come in the form of measurable indexes, such as high GDP growth or decreasing unemployment rate. However, although such approach dominates empirical research on regional development, it accounts only for the long-term results of governance. Therefore, it is recommended that researchers also examine those results of innovation that lead to building or strengthening civil society and social capital in a given region.

These three dimensions of the proposed analytical model are equally important. Many concepts emphasise the significance of institutions and networked organisation as the autotelic social value ${ }^{45}$. In the above-mentioned model we also put emphasis on the effects of implementation of the new ideas and solutions. The positive change which is

45 R.A.W. Rhodes, Understanding Governance. Policy Networks, Governance, Reflexivity and Accounability, Midenhead 2010. 
reflected in the improvement of the quality of goods and services offered by public sector has to be a part of the process of implementing of innovation.

Undoubtedly, innovation constitutes a source of changes positive for those who introduce it. Regardless of what type of innovation is considered, it requires an attitude of openness and creativity based on constantly broadened knowledge. Still, managerial innovation seems to rely on receptiveness to new ideas, concepts, solutions and changes to an even greater extent than any other type. It also calls for the ability to observe and learn, to absorb and operationalise knowledge into a specific action.

Innovation in managing regions entails shifting away from traditional paradigms that have so far dominated this sphere. It results in new processes, practices or structures of management ${ }^{46}$ that allow one region to act differently from others. The importance of innovation in regional governance stems from the fact that it is meant to evoke positive changes, which will not only speed up the socio-economic growth, but also foster social capital of a given geographical area. This, in turn, is crucial to how willing society will be to legitimise such innovative solutions aimed at regional development.

\section{Conclusions}

A methodological approach to analysing innovation in regional governance requires most of all the understanding of regional governance itself. The concept was born from theories of public management, under realities of a multi-level political system. Then, one has to define which of the many implemented managerial tools and solutions can truly be considered innovative within the framework of regional governance. This task is by no means easy or obvious, as the meaning of innovation may differ depending on the social, economic and cultural context of a particular territory where it is being developed and implemented. Upon analysing different ways of interpreting innovation in regional governance, one comes to the conclusion that its novel character results from institutionalised (to a greater or lesser extent) contacts and cooperation between the regional administration and the broadly understood civil society. The three-part model for analysing innovation in regional governance proposed here, encompassing subjects, decision-making processes and political effects, provides a tool to be used in empirical research on specific local or regional geographical units.

Applying the concept of organisational innovation to regional governance seems to produce a fresh take on the subject and promises to bring answers to questions about potential factors determining effectiveness and efficiency of regional development policies. In the light of regional governance principles presented in this paper, managerial innovation may serve to build and strengthen regional civil societies that, in a democratic political system, act not as mere recipients, but genuine subjects of the political process aimed at pursuing the common interest.

${ }^{46}$ M. Prudzienica, 'Zarządzanie wiedzą w kreowaniu innowacji zarządczych', [in:] Zarządzanie wiedzą w kreowaniu innowacji zarzadczych, ed. M. Morawski, M. Prudzienica, Wrocław 2009, p. 36. 


\section{Bibliography}

Alberti A., Bertucci G., 'Replicating Innovations in Governance: An Overview', [in:] Innovations in Governance and Public Administration. Replicating What Works, ed. A. Alberti, G. Bertucci, New York 2006, http://unpan1.un.org/intradoc/groups/public/documents/un/unpan021963.pdf, (retrieved: 4.10.2015).

Anttiroiko A.V., Bailey S.J., Valkama P., 'Innovations in Public Govenance in the Western World', [in:] Innovations in Public Governance, ed. A.V. Anttiroiko, S.J. Bailey, P. Valkama, Amsterdam 2011, pp. 1-22.

Bailey D., De Propris L., 'EU Structural Funds, Regional Capabilities and Enlargement: Towards Multi-Level Governance?', Journal of European Integration, 24 (2002).

Bason C., Leading Public Sector Innovation: Co-Creating for a Better Society, Bristol 2010.

Benz Z., Governance - Regieren in komplexen Regelsystemen: Eine Einführung, Wiesbaden 2004.

Birkinshaw J., Hamel G., Mol M.J., 'Management Innovation', Academy of Management Review, 33/4 (2008).

Borys T., 'Koncepcja dobrego rządzenia - istota, cechy swoiste, pomiar', [in:] Dobre rzadzenie w gminach małych. Empiryczny wymiar nowego paradygmatu rozwoju, vol. 1, ed. K. Kobielska, A. Lisowska, Bydgoszcz 2014.

Börzel T.A., 'Nowe metody zarządzania, a rozszerzenie Unii Europejskiej — paradoks podwójnej słabości', [in:] Nowe metody zarzadzania w państwach Unii Europejskiej, ed. L. Kolarska- Bobińska, Warszawa 2009.

Bott J., Die Wirkung von Macht auf Innovationen innerhalb einer öffentlichen Verwaltung, Kassel 2013.

Brzeziński M., Zarządzanie innowacjami technicznymi i organizacyjnymi, Warszawa 2001.

Diedrichs U., 'Metody zarządzania w Unii Europejskiej', [in:] Nowe metody zarządzania w państwach Unii Europejskiej, ed. L. Kolarska- Bobińska, Warszawa 2009.

Eggers W.D., Singh S.K., The Public Innovation's Playbook: Nurturing Bold Ideas in Government, Ash Institute for Democratic Governance and Innovation, John F. Kennedy School of Government, Harvard University 2009, http://www.innovations.harvard.edu/public-innovators-playbook-nurturing-bold-ideas-government (retrieved: 4.10.2015).

European Commission, Europe 2020. A European Strategy for Smart, Sustainable, and Inclusive Growth, Brussels 2014, http://ec.europa.eu/europe2020/europe-2020-in-a-nutshell/priorities/smart-growth/index_en.htm (retrieved: 4.10.2015).

Geißel B., 'Zur (Un)Möglichkeit von Local Governance und Zivilgesellschaft. Konzepte und empirische Befund', [in:] Local Governance - mehr Transparenz und Bürgernähe, ed. L. Schwalb, H. Walk, Wiesbaden 2007.

Geodecki T., Mamica Ł, Polityka innowacyjna, Warszawa 2014.

Grote R.J., 'Local Governance und organisierte Zivilgesellschaft', [in:] Local Governance - mehr Transparenz und Bürgernähe, ed. L. Schwalb, H. Walk, Wiesbaden 2007.

Grunow D., Innovationen in der öffentlichen Verwaltung, Handbuch Innovationen. Interdisziplinäre Grundlagen und Anwendungsfelder, Wiesbaden 2014.

Hambleton R., Howard J., 'Place-Based Leadership and Public Service Innovation', Local Government Studies, 39/1 (2013).

Haus M., 'Governance, Meta-Governance und die Transformationen lokaler Institutionen', [in:] (eds.), Local Governance - mehr Transparenz und Bürgernähe, ed. L. Schwalb, H. Walk, Wiesbaden 2007.

Hausner J., Zarzadzanie publiczne, Warszawa 2008.

Hooghe L., Marks G., Multi-Level Governance and European Integration, Lanham 2001.

Kozioł-Nadolna K., Janosz W., Innowacje w organizacji, Warszawa 2011.

Kożuch B., 'Innowacyjność w zarządzaniu publicznym', [in:] Nowe zarządzanie publiczne i public governance $w$ Polsce $i$ w Europie, ed. A. Bosiacki et al., Warszawa 2010.

Kożuch B., Kożuch A., 'Innowacyjność z zarządzaniu rozwojem lokalnym', Journal of Agrobusiness and Rural Development, $3 / 25$ (2012).

Kraśnicka T., 'Innowacyjność zarządzania w rozwoju współczesnych organizacji (aspekty teoretyczne)', [in:] Strategie zarządzania organizacjami w społeczeństwie informacyjnym, ed. A. Stabryła, T. Małkus Kraków 2014. 
Kuźnik F., 'Stare i nowe koncepcje zarządzania publicznego w strukturach samorządu terytorialnego', [in:] Z teorii i praktyki zarządzania publicznego, ed. B. Kożuch, T. Markowski, Białystok 2005.

Lisiecka K., Papaj T., Czyż-Gwiazda E., Public Governance koncepcją zarządzania w administracji publicznej, Katowice 2011.

Makieła Z., Przedsiębiorczość i innowacyjność terytorialna. Region w warunkach konkurencji, Warszawa 2013.

Maloney W., Smith G., Stoker G., 'Social Capital and Urban Governance: Adding a More Contextual “TopDown" Perspective', Political Studies, 48 (2000).

Markowski T., Banachowicz B., 'Innowacyjność w samorządzie terytorialnym', [in:] Z teorii i praktyki zarządzania publicznego, ed. B. Kożuch, T. Markowski, Białystok 2005.

Michalewska-Pawlak M., 'Europeizacja samorządu - wpływ Unii Europejskiej na aktorów lokalnych i regionalnych', [in:] Europeizacja - mechanizmy, wymiary, efekty, ed. A. Pacześniak, R. Riedel, Toruń 2010.

Miłek D., 'Specjalizacje regionalne a Strategia Europa 2020', Journal of Management and Finance, 11/1 (2013), part 2, Sopot 2013.

Moore M.H., Hartley J., 'Innovations in Governance', [in:] The New Public Governance? Emerging Perspectives on the Theory and Practice of Public Governance, ed. S.P. Osborne, London 2010.

Narastające dysfunkcje, zasadnicze dylematy, konieczne działania. Raport o stanie samorządności terytorialnej w Polsce, ed. J. Hausner, Kraków 2013.

Niedzielski P., Rychlik K., Innowacje i kreatywność, Szczecin 2006.

Osborne S.P., Brown L., 'Innovation, public policy and public services delivery in the UK. The word that would be king?', Public Administration, 84/4 (2001), pp. 1335-1350.

Pawlik A., Potencjat innowacyjny w rozwoju regionalnym, Kielce 2012.

Penc J., Innowacje i zmiany w firmie, Warszawa 2011.

Podgórniak-Krzykacz A., 'Rozwój lokalny a dobre rządzenie - przegląd wybranych założeń wybranych strategii rozwoju lokalnego', Zeszyty Naukowe Wyższej Szkoły Zarządzania i Finansów, 27 (2009).

Pollitt C., 'Innovation in the Public Sector: An Introductory Overview', [in:] Innovation in the Public Sector - Linking Capacity and Leadership, ed. V. Bekkers, J. Edelenbos, B. Steijn New York 2011.

Prudzienica M., 'Zarządzanie wiedzą w kreowaniu innowacji zarządczych', [in:] Zarządzanie wiedzq w kreowaniu innowacji zarządczych, ed. M. Morawski, M. Prudzienica, Wrocław 2009.

Pytlak K. et al., Procesy innowacyjne a rozwój regionu, Lublin 2014.

Rhodes R.A.W., Understanding Governance. Policy Networks, Governance, Reflexivity and Accountability, Midenhead 2010.

Rothwell R., 'Developments towards the Fifth Generation Model of Innovation', Technology Analysis and Strategic Management, 4/1 (1992).

Schumpeter J.A., Teoria rozwoju gospodarczego, Warszawa 1960.

Supernat J., 'Administracja publiczna, governance i nowe publiczne zarządzanie', [in:] Prawna działalność instytucji społeczeństwa obywatelskiego, ed. J. Blicharz, J. Boć, Wrocław 2009.

Tuziak A. et al., Innowacyjność i rozwój, Rzeszów 2006.

United Nations, Resolution adopted by the General Assembly: Promoting and consolidating democracy, A/RES/55/96, New York 2000.

Wiktorska-Święcka A., 'Governance jako nowy paradygmat sterowania rozwojem w procesach integracji europejskiej', [in:] Procesy integracyjne i dezintegracyjne w Europie. Podręcznik akademicki, ed. M. Klimowicz, A. Pacześniak, Wrocław 2014. 


\section{Understanding the concepts of innovation in regional governance}

Summary

The purpose of this paper is to present the concepts of innovation in regional governance - both their theoretical foundations and empirical dimension. The concepts proposed here are rooted in the public management model, while the idea of regional governance is based on the framework of a multi-level system of making and implementing political decisions. The article analyses definitions of innovation and the process of its implementation. This, in turn, provides a research tool for examining regional governance. The authors present a definition of innovation in public management - a sphere oriented toward meeting common needs of society, as contrasted with the market-oriented private sector. They proceed to pointing out the doctrinal sources of pursuing innovation in public management: theories of democracy, civil society, knowledge, social capital and networks. Finally, they propose a three-part analytical model for examining innovation in regional governance. The study is based on a typical scientific literature review using the following research methods: analysis, synthesis and theoretical modelling. 